\title{
Tongue carcinoma infrequently harbor common actionable genetic alterations
}

\author{
Daniel SW Tan ${ }^{1,2^{*}}$, Weining Wang ${ }^{3}$, Hui Sun Leong ${ }^{1}$, Pui Hoon Sew ${ }^{1}$, Dawn P Lau', Fui Teen Chong ${ }^{1}$, \\ Sai Sakktee Krisna', Tony KH Lim ${ }^{4}$ and N Gopalakrishna lyer ${ }^{1,3^{*}}$
}

\begin{abstract}
Background: Oral tongue squamous cell carcinomas (TSCC) are a unique subset of head and neck cancers with a distinct demographic profile, where up to half of the cases are never smokers. A small proportion of patients with OSCC are known to respond to EGFR TKI. We used a high-sensitivity mass spectrometry-based mutation profiling platform to determine the EGFR mutation status, as well as other actionable alterations in a series of Asian TSCC.
\end{abstract}

Methods: 66 TSCC patients treated between 1998-2009 with complete clinico-pathologic data were included in this study. Somatic mutation profiling was performed using Sequenom LungCarta v1.0, and correlated with clinical parameters.

Results: Mutations were identified in 20/66(30.3\%) of samples and involved TP53, STK11, MET, PIK3CA, BRAF and NRF2. No activating EGFR mutations or KRAS mutations were discovered in our series, where just over a third were never smokers. The most common mutations were in p53 $(10.6 \% ; n=7)$ and MET $(10.6 \%, n=11)$ followed by STK11 $(9.1 \%, n=6)$ and PIK3CA $(4.5 \%, n=3)$. BRAF and NRF2 mutations, which are novel in TSCC, were demonstrated in one sample each. There was no significant correlation between overall mutation status and smoking history $(p=0.967)$ or age $(p=0.360)$. Positive MET alteration was associated with poorer loco-regional recurrence free survival (LRFS) of 11 months [vs 90 months in MET-negative group $(p=0.008)$ ]. None of the other mutations were significantly correlated with LRFS or overall survival. Four of these tumors were propagated as immortalized cell lines and demonstrated the same mutations as the original tumor.

Conclusions: Using the Sequenom multiplexed LungCarta panel, we identified mutations in 6 genes, TP53, STK11, MET, PIK3CA, BRAF and NRF2, with the notable absence of EGFR and HER2 mutations in our series of Asian OSCC. Primary cell line models recapitulated the mutation profiles of the original primary tumours and provide an invaluable resource for experimental cancer therapeutics.

Keywords: Druggable, Therapeutic, Squamous cell carcinoma, Sequenom, Oral cancers, HNSCC

\section{Background}

Oral squamous cell carcinoma (OSCC) is a significant world-wide public health threat accounting for approximately 270,000 cases with 145,000 deaths annually $[1,2]$. The highest prevalence is seen in developing countries and five-year survival rates remain less than 50\% [1-3]. The majority originate from the anterior tongue, and less commonly from the buccal cavity, alveolus, floor of

\footnotetext{
* Correspondence: daniel.tan.s.w@nccs.com.sg; gopaliyer@yahoo.com

'Cancer Therapeutics Research Laboratory, National Cancer Centre Singapore, 11 Hospital Drive, Singapore 169610, Singapore

2 Department of Medical Oncology, National Cancer Centre, 11 Hospital Drive, Singapore 169610, Singapore

Full list of author information is available at the end of the article
}

mouth, retromolar trigone and hard palate. Several reports have suggested an increase in incidence of OSCC over recent years, afflicting not only those of lower socioeconomic status and developing countries, but also in developed countries such as the US and UK [4-7]. Moreover, a proportion of cases occur in younger patients who are never smokers, with no relation to betel nut chewing or smoking, common risk factors for oral cancers [8,9]. There is also evidence to suggest that the various subsites within the oral cavity exhibit significant differences in clinical behavior that are not attributable to the pathogenesis alone $[10,11]$. This has prompted several investigators to focus studies on specific subsites, including large scale 
next-generation sequencing efforts initiated by the International Cancer Genome Consortium (ICGC) [12].

The rapidly expanding repertoire of targeted therapeutics against key somatic alterations has led to increased endeavors towards pathway-driven approaches to treating cancer. For example, head and neck and lung cancers are well known to have activated EGFR pathway, and this has led to focused development of drugs that either directly inhibit the EGFR receptor such as monoclonal antibodies like cetuximab, block the tyrosine kinase activity (small molecules including gefitinib, erlotinib, afatanib etc) or molecules that block the downstream signal transduction cascade (targeting Phosphoinositide 3kinase (PI3K), mammalian target of rapamycin (mTOR) etc) [13]. Specific activating EGFR mutations act as a predictive marker for tyrosine kinase inhibitors such as gefitinib and erlotinib in NSCLC, and have conferred significant improvement in overall survival [14]. Clinical activity of EGFR tyrosine kinase inhibitors (TKI) has also been examined in head and neck cancer, where responses have been seen in up to $15 \%$ but there is no correlation between response and EGFR mutations [15-24]. Few studies have looked for EGFR mutations and other "actionable mutations" in OSCC, and most to date have been conducted in small heterogeneous HNSCC patient cohorts. Studies focused on oral or tongue squamous cell carcinoma show possible population differences in prevalence for EGFR mutation rates, suggesting ethnic differences may exist [24-37]. Similarly, large scale sequencing efforts in HNSCC by several collaborative groups have focused mainly in Caucasian populations, revealing common mutations in genes such as p53, p16, Notch, FAT1, H-Ras and Caspase 8 [24,26,27,38]. Recently Zanaruddin et al. reported the use of Sequenom Oncocarta to profile 112 oral SCC samples in Asian patients [39]. While potentially actionable mutations such as PIK3CA and HRAS were reported in that study, tongue cancers only comprised $30 \%$ of patients.

Due to the potential similarities among aerodigestive tract cancers, we adopted the Sequenom LungCarta panel to comprehensively evaluate a set of 66 Asian tongue cancers for EGFR mutation status, as well as other commonly implicated "actionable" or "druggable" oncogenes and tumour suppressor genes and correlated these with clinic-pathologic and outcome data.

\section{Methods}

\section{Patients and tissue collection}

Patients were identified from an institutional database of consecutive patients treated at the National Cancer Centre Singapore (NCCS) between January 1998 and March 2009. Included patients were confirmed to have a histological diagnosis of squamous cell carcinoma involving the anterior tongue, with complete clinico-pathologic data and fresh, frozen tumor samples available. Treatment decisions were made in weekly multi-disciplinary meetings and recorded prospectively. Only patients with no prior treatment for their cancers were included in this study and all patients were treated with upfront surgery followed by adjuvant therapy if applicable. Fresh tumor samples for sixty-six patients were retrieved from Singhealth Tissue Repository, with standardized written consent for use of clinical material (with covers tumor tissue, blood or other clinical specimens) and clinic-pathologic data for research. Both this study and the tissue collection/consent protocol have been approved by the Singhealth Centralized Institutional Review Board.

\section{Tissue preparation and DNA extraction}

For all samples, tumor content was first determined by microscopic examination of hemotoxylin and Eosin (H\&E) stained sections of the tissue by a board-certified pathology (TKL). DNA was only extracted from specimens determined to have $>50 \%$ tumor content. DNA extraction was performed using a $3 \mathrm{~mm} \times 3 \mathrm{~mm}$ section of freshfrozen tissue using the Qiamp DNA extraction kit (Qiagen, Valencia, CA) according to the manufacturer's instructions. However, the sample DNA was eluted in molecular grade water instead of TE Buffer. The DNA concentration and purity were quantified and assessed using the Nanodrop 2000 spectrophotometer (Thermo Scientific, Wilmington, DE). All samples yielded excellent DNA quality with A260/A280 ratio greater than 1.60.

\section{Somatic mutation profiling using Sequenom LungCarta v1.0} Somatic mutation profiling was accomplished by using the Sequenom LungCarta v1.0 panel (http://www.sequenom. com) (Sequenom, San Diego, CA). The panel interrogated 214 somatic mutations across 26 oncogenes and tumor suppressors using the MassARRAY 4 System using multiplex PCR (Sequenom, San Diego, CA). Targeted mutation profiling was performed using the Sequenom Massarray 4 platform (Sequenom, San Diego, CA). Samples were evaluated for 214 mutations in a 24-multiplex PCR format using the LungCarta panel and analyzed on the matrix-assisted laser desorption ionization-time of flight mass spectrometry (MALDI-TOF) Sequenom platform. LungCarta panel provides evaluation of 214 somatic mutations in 26 oncogenes and tumour suppressor genes acting in key pathways in lung cancer (Table 1). Data extraction was performed using Sequenom MassArray Typer Analyzer software. Mutations were determined using a minimum $10 \%$ threshold of the mutant allele peak.

An ion exchange resin (CLEAN Resin, Sequenom, San Diego, CA) was used to remove salt adducts. $41 \mu \mathrm{l}$ of water was added to give a final volume of $50 \mathrm{ul}$ after which the resin was added into the wells. The plates 
Table 1 LungCarta 1.0- lung panel gene targets

\begin{tabular}{|c|c|c|c|}
\hline Gene & Mutation & Gene & Mutation \\
\hline AKT1 & E17K & MET & N375S, 982_1028del47 \\
\hline ALK & C1156Y, L1196M & $\mathrm{NOTCH} 1$ & $\begin{array}{l}\text { H2276fs*79, D1643H, R2328W, T1997M, V1672I, } \\
\text { V2444fs*35 }\end{array}$ \\
\hline BRAF & D594G/M, G469S/E/AN, L597Q/N, V600E/K/M & NRAS & Q61E/K/H/L/R/P \\
\hline DDR2 & C580Y, D125Y, G253C, G505S, G774EN, I120M, 1638F, L239R, L63V, T765P & NRF2 & D29H, D77N/A, E79Q/K/G, G31A, G81D, R34Q, \\
\hline EGFR & 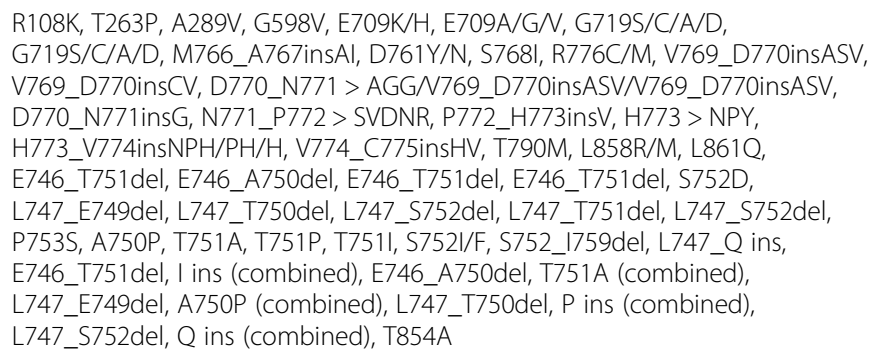 & NTRK1 & Q80*, R119H, S326R \\
\hline EPHA3 & $\begin{array}{l}\text { A435S, D446Y, S449F, D806N, G187R, G518L, K761N, G766E, M269I, } \\
\text { N379K, N85S, S229Y, T166N, T37K, T393K, W250R }\end{array}$ & NTRK2 & Q666R, C45F, G261R, L138F, L670M, L755L \\
\hline EPHA5 & D493Y, G582E, M1034I, N1032S, R1007Q, S566Y, S810l, T856I & NTRK3 & $\begin{array}{l}\text { I769N, L152I, L248M, L270M, L336Q, S184C, } \\
\text { T283K, V307L, R271F }\end{array}$ \\
\hline ERBB2 & M774_A775insAYVM, A775_G776insAYVM & PIK3CA & $\mathrm{E} 542 \mathrm{Q} / \mathrm{K}, \mathrm{E} 545 \mathrm{Q} / \mathrm{K} . \mathrm{H} 1047 \mathrm{Y} / \mathrm{R} / \mathrm{L}$ \\
\hline FGFR4 & P672T, H192fs*19 & PTCH1 & R1308G, R682L, S1326fs*46 \\
\hline JAK2 & L609S, P503L, R1122P, Y931C & PTEN & $\mathrm{R} 233^{*}$ \\
\hline KRAS & G12S/N/F/R/A/C/D, G13C/S/AN/DQ61L/R/P/H/E/K & PTPN11 & E76V \\
\hline MAP2K1 & D67N, K57N, Q56P & PTPRD & $\begin{array}{l}\text { D1162N, D154Y, 144I, L1036Q, P1809R, R1536L, } \\
\text { R584S, S1703R, T337A, V483E }\end{array}$ \\
\hline STK11 & $\begin{array}{l}\text { A347fs*13, A43_L50del6, D327fs*10, E120*, E165*, E223*, E70*, E70fs*26, } \\
\text { F354L, G163C, G188fs*99, G196V, G56fs*4, G56W, G91L, H174R, I26fs*25, } \\
\text { K191*, K78E, L285Q, L50_D53del4, M51fs*14, P179L, Q123R, Q137*, Q159*, } \\
\text { Q170*, Q220*, Q37L, R426W, R86G, V197fs*69, V236fs*30, Y272Y }\end{array}$ & TP53 & $\begin{array}{l}\text { G245C/S, G245D/N, R158C/G/L/P, R175L/H, } \\
\text { R248L/Q/R/W, R249S/W/M, R273C/H/L/P, } \\
\text { R282G/W, V157F, Y163C,R175L/H Y220C }\end{array}$ \\
\hline
\end{tabular}

*Frameshift or truncating mutation.

were incubated with the resin for 20 to 30 minutes. The samples were transferred onto the SpectroChip-II (96well to 96-chip configuration) using the MassARRAY Nanodispener RS1000 (Sequenom, San Diego, CA). The dispense speed was at $70 \mathrm{~mm} / \mathrm{sec}$ but was adjusted accordingly to ensure a consistent spotting volume range of 8 to $10 \mathrm{~nL}$ with a standard deviation of less than 3.5 . The samples were resolved using the Matrix-Assisted Laser Desorption/Ionization Time-of-Flight (MALDI-TOF) mass spectrometer (Sequenom, San Diego, CA).

\section{Data analysis}

Mutational analysis was accomplished using the Sequenom Typer Analyzer 4.0 software (Sequenom, San Diego, CA). The mutation detection threshold was set at $10 \%$. The system provided a mutation list that showed the mutations that were picked up by the mass spectrometer. The mutations were sorted according to 3 different confidence levels (High, Medium and Low) based on peak height, morphology, statistical Z-score and allele frequencies [40,41]. For all medium and high confidence calls, the electrophorograms were manually checked. For difficult cases, a second opinion was required. Only cases regarded as true are included in this list, and all the true cases in this situation were called with high confidence (see below). These experiments and analysis were performed in parallel with a series of lung cancer primary tissue and cell lines which served as positive controls for a range of mutations [40].

\section{Statistical analysis}

Statistical analyses were performed using SPSS software. Student's t test was used to compare group means while chi-square test and Fisher's exact test were used to analyze other factors. Mean overall survival (OS) and disease-free survival (LRFS) were calculated. KaplanMeier plots were plotted and log-rank test was performed to compare the plots. In all statistical analyses, a $\mathrm{p}$ value of less than 0.05 was considered statistically significant.

\section{Results}

Details of patient characteristics are shown in Table 2. In this cohort, 46 (69.7\%) were male and 37 (56.1\%) were 
Table 2 Clinico-pathologic characteristics of patients with tongue squamous cell carcinoma in this study $(n=66)$

\begin{tabular}{|c|c|}
\hline Characteristics & Number (\%) \\
\hline \multicolumn{2}{|l|}{ Sex: } \\
\hline Male & $46(69.7 \%)$ \\
\hline Female & $20(30.3 \%)$ \\
\hline \multicolumn{2}{|l|}{ Smoker: } \\
\hline Never & $25(37.9 \%)$ \\
\hline Ever & $37(56.1 \%)$ \\
\hline Unknown & $4(6.1 \%)$ \\
\hline \multicolumn{2}{|c|}{ Clinical T-classification } \\
\hline $\mathrm{T} 1 / \mathrm{T} 2$ & $21(31.8 \%)$ \\
\hline $\mathrm{T} 3 / \mathrm{T} 4$ & $40(60.6 \%)$ \\
\hline Tx & $5(7.6 \%)$ \\
\hline \multicolumn{2}{|c|}{ Clinical N-classification } \\
\hline No & $26(39.4 \%)$ \\
\hline $\mathrm{N}+$ & $39(59.1 \%)$ \\
\hline Unknown & $1(1.5 \%)$ \\
\hline \multicolumn{2}{|c|}{ Adjuvant radiation or chemoradiation therapy: } \\
\hline Radiotherapy only & $30(45.5 \%)$ \\
\hline Chemoradiotherapy & $6(9.1 \%)$ \\
\hline N & $20(30.3 \%)$ \\
\hline Unknown & $10(15.2 \%)$ \\
\hline \multicolumn{2}{|c|}{ Extra-capsular spread } \\
\hline Y & $15(22.7 \%)$ \\
\hline N & $16(24.2 \%)$ \\
\hline Not applicable & $24(36.4 \%)$ \\
\hline Unknown & $11(16.7 \%)$ \\
\hline \multicolumn{2}{|c|}{ Lymphovascular and/or perineural invasion } \\
\hline Y & $31(47.0 \%)$ \\
\hline N & $20(30.3 \%)$ \\
\hline Unknown & $15(22.7 \%)$ \\
\hline \multicolumn{2}{|l|}{ Recurrence } \\
\hline Y & $28(42.4 \%)$ \\
\hline N & $29(43.9 \%)$ \\
\hline Unknown & $14(13.6 \%)$ \\
\hline
\end{tabular}

ever-smokers. The median age at diagnosis was 63 years (range: 22-89 years). The majority of patients had locally advanced disease (T3/T4) $(n=40 / 60.6 \%)$. All patients in this cohort underwent surgery as the primary modality of treatment, and 36 (54.5\%) received adjuvant radiation or chemo-radiation therapy. Patients were followed up for a median of 18 months (Range: 3 - 60 months). During this time period, there were $28(42.4 \%)$ recurrences and $15(22.7 \%)$ deaths. These were all cancers of the anterior tongue, and there was no evidence of involvement of human papillomavirus (HPV) in any of the tumors (manuscript in preparation- Iyer NG, Tan DSW).

Analyses of the Sequenom data showed that in total there were 42 high, 60 medium and 353 low confidence calls. Manual verification confirmed that of these 24 alterations were deemed to be true an included in further analysis, and all of these were derived from high confidence calls. The 24 alterations were identified in 20 (30.3\%) tumors using the LungCarta 1.0 panel (Table 2). These were distributed across six genes: TP53, STK11, MET, PIK3CA, BRAF and NRF2 and the distribution of mutations across samples are indicated in Figure 1. There were thirteen unique alterations identified, with 16 tumors having a single variations and four tumors having two separate variations (Table 3). The commonest alterations seen were MET (10.6\%; $\mathrm{n}=7)$, TP53 (10.6\%; $\mathrm{n}=7)$, STK11 (9.1\%; $\mathrm{n}=6)$. Three PIK3CA mutations were "activating" (one with E542K and two with H1047N mutations). One tumor harbored a BRAF (D594G) mutation and another with a mutation in NRF2 (G31A), both of which are novel in TSCC, and the mutations have been validated through next-generation target re-sequencing of the same samples (manuscript in preparation). Tumor cells were propagated in culture as previously described [42]. In samples identified to have mutations, four (out of six attempted) have been successfully propagated in culture as cell lines: NPC7, TM24, TM44 and TM47 and profiling the cell lines confirmed that these harbored the same genetic alterations as the primary tumor they were derived from (Table 3).

There was no significant association between smoking history and the presence of any mutation detected by the LungCarta panel $(\mathrm{p}=0.967)$, or specific alterations in MET $(\mathrm{p}=0.806), \mathrm{p} 53(\mathrm{p}=0.520)$ and STK11 $(\mathrm{p}=0.105)$ (Table 3). There was also no correlation between patient age and mutation status $(\mathrm{p}=0.360)$. With regards to outcome analyses, there were no significant correlations between the presence of any mutation and overall survival (OS) or loco-regional recurrence-free survival (LRFS). Median OS was 78 and 106 months $(\mathrm{p}=0.711)$, while median LRFS was 56 and 93 months $(\mathrm{p}=0.670)$ for patients with and without any mutations detected by this assay respectively. Similarly, there was no correlation between the presence of p53 or STK11 mutations and outcome. Interestingly, however, the presence of the MET N375S variant was associated with poorer loco-regional recurrence rates compared to patients who did not harbor this mutation: median LRFS of 11 versus 90 months respectively $(\mathrm{p}=0.008)$ (Figure $2 \mathrm{a})$. A trend to poorer survival was also seen when analyzing overall survival, where the median OS was 31 months in patients with MET mutation compared to 103 months in patients without although this was not statistically significant $(\mathrm{p}=0.287)$ (Figure $2 \mathrm{~b})$. 


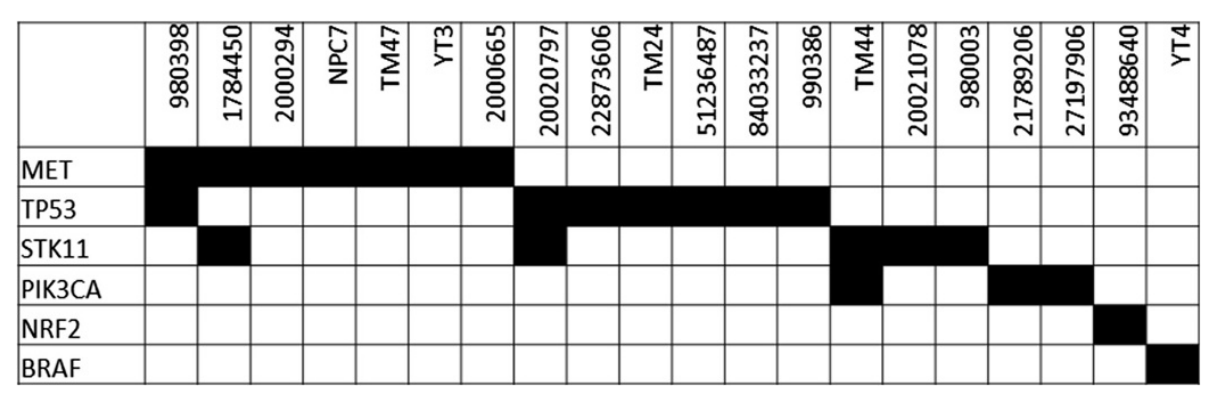

Figure 1 Co-mutation map of samples identified to have at least one mutation in MET, TP53, STK11, PIK3CA, NRF2 and BRAF.

\section{Discussion and conclusions}

Oral squamous cell carcinoma remains a devastating disease with few treatment options in the metastatic setting. In this study, we used a panel designed for lung cancer to identify mutations in oral tongue cancer. Of the mutations tested, we only identified alterations in six genes in only 20 samples - TP53, STK11, MET, PIK3CA, BRAF and NRF2. Importantly, EGFR and KRAS mutations were not found in Asian tongue cancers, and this represents one of the largest series to date comprehensively

Table 3 Specific mutations and clinic-pathologic features samples where mutations were detected $(n=20)$

\begin{tabular}{|c|c|c|c|c|c|c|c|c|c|}
\hline Sample & Gene & Mutation & TNM & $\begin{array}{l}\text { Overall } \\
\text { stage }\end{array}$ & Age/sex & $\begin{array}{l}\text { Smoking } \\
\text { status }\end{array}$ & $\begin{array}{l}\text { Adjuvant } \\
\text { treatment }\end{array}$ & Outcome & $\begin{array}{l}\text { Time to } \\
\text { recurrence } \\
\text { (Months) }\end{array}$ \\
\hline \multicolumn{10}{|c|}{ Tumors with a single mutation } \\
\hline 2000294 & MET & N375S & TxN2bM1 & 4 & $53 / \mathrm{M}$ & Ever & Yes & Recurrence & 7 \\
\hline 20021078 & STK11 & F354L & $\mathrm{T} 4 \mathrm{aN} 1 \mathrm{M0}$ & 4 & $79 / \mathrm{M}$ & Ever & Yes & No Recurrence & N.A. \\
\hline 21789206 & PIK3CA & E542K & T4aNOMO & 4 & $54 / \mathrm{M}$ & Ever & Yes & Recurrence & 33 \\
\hline 22873606 & TP53 & $\mathrm{R} 175 \mathrm{H}$ & T4aNOMO & 4 & $75 / M$ & Ever & No & Unknown & N.A. \\
\hline 27197906 & PIK3CA & H1047R & T4aNOMO & 4 & $56 / M$ & Ever & Yes & Unknown & N.A. \\
\hline$N P C 7^{*}$ & MET & N375S & T4N2bM0 & 4 & $22 / F$ & Ever & Yes & Recurrence & 6 \\
\hline TM24* & TP53 & R282W & T2N2bM0 & 4 & $60 / M$ & Ever & Yes & Recurrence & 15 \\
\hline TM47* & MET & N375S & T4aN2cM0 & 4 & $76 / M$ & Ever & Yes & Recurrence & 6 \\
\hline 93488640 & NRF2 & G31A & T2N1M0 & 3 & $61 / M$ & Never & Yes & Recurrence & 31 \\
\hline 51236487 & TP53 & R273P & T2NOMO & 2 & $60 / M$ & Never & Yes & Unknown & N.A. \\
\hline 84033237 & TP53 & R273C & T4aN2bM0 & 4 & $56 / M$ & Never & No & Recurrence & 24 \\
\hline 980003 & STK11 & F354L & T2NOMO & 2 & $39 / M$ & Never & No & Unknown & N.A. \\
\hline$Y T 3^{* *}$ & MET & N375S & T3NOMO & 3 & $52 / F$ & Never & No & Unknown & N.A. \\
\hline YT4 & BRAF & D594G & T1N0M0 & 1 & $42 / F$ & Never & No & No Recurrence & N.A. \\
\hline 990386 & TP53 & $\mathrm{R} 175 \mathrm{H}$ & T4aNOMO & 4 & $63 / M$ & Unknown & Unknown & No Recurrence & N.A. \\
\hline 2000665 & MET & N375S & T4aN2bM0 & 4 & $53 / F$ & Unknown & Yes & No Recurrence & N.A. \\
\hline \multicolumn{10}{|c|}{ Tumors with two separate mutations } \\
\hline \multirow[t]{2}{*}{980398} & MET & N375S & $\mathrm{T} 2 \mathrm{~N} 1 \mathrm{MO}$ & 3 & $61 / M$ & Never & No & No Recurrence & N.A. \\
\hline & TP53 & G245S & & & & & & & \\
\hline \multirow[t]{2}{*}{1784450} & MET & N375S & T4aN2cM0 & 4 & $66 / M$ & Ever & No & Recurrence & 5 \\
\hline & STK11 & F354L & & & & & & & \\
\hline \multirow[t]{2}{*}{20020797} & STK11 & F354L & T4aN2cM0 & 4 & $69 / M$ & Ever & Yes & No Recurrence & N.A. \\
\hline & TP53 & Y163C & & & & & & & \\
\hline \multirow[t]{2}{*}{$\mathrm{TM}_{4}^{* * *}$} & PIK3CA & H1047L & T2N2bM0 & 4 & $62 / M$ & Ever & Yes & No Recurrence & N.A. \\
\hline & STK11 & F354L & & & & & & & \\
\hline
\end{tabular}

*Successfully propagated as cell line.

**Refused conventional treatment and lost to follow-up.

***Successfully propagated as cell line, patient had a 30-day mortality after primary surgery. 
a

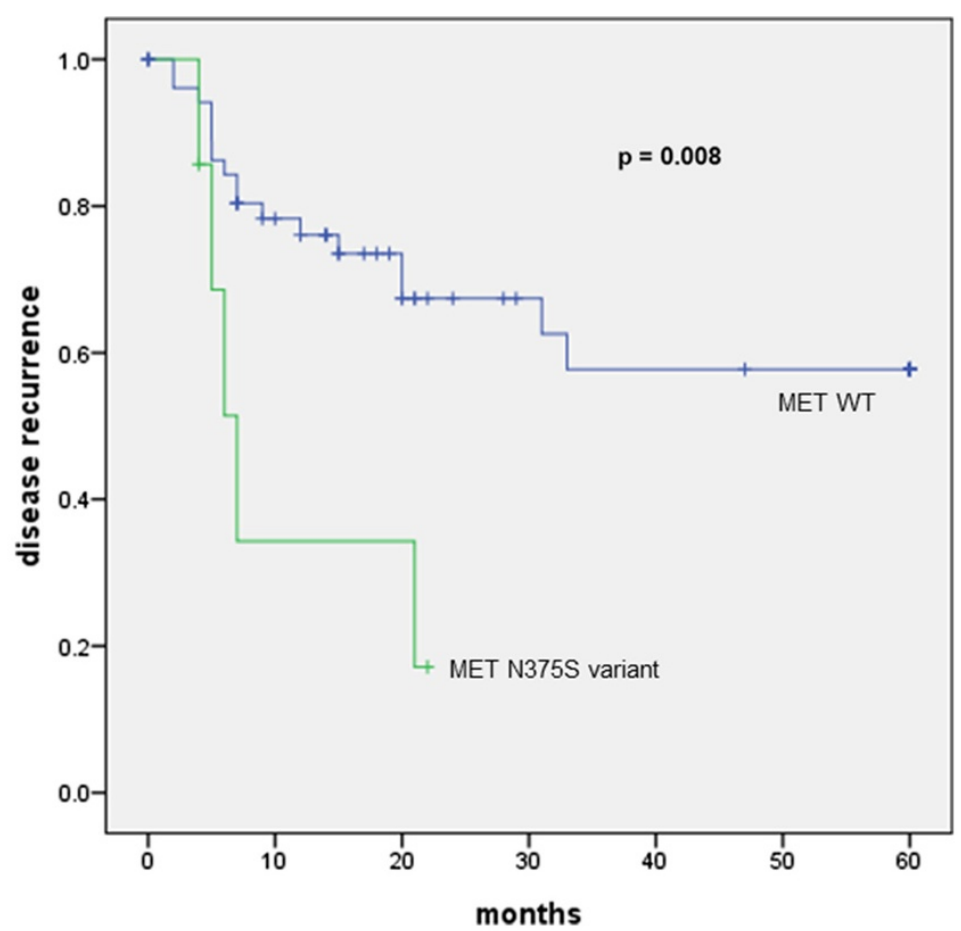

b

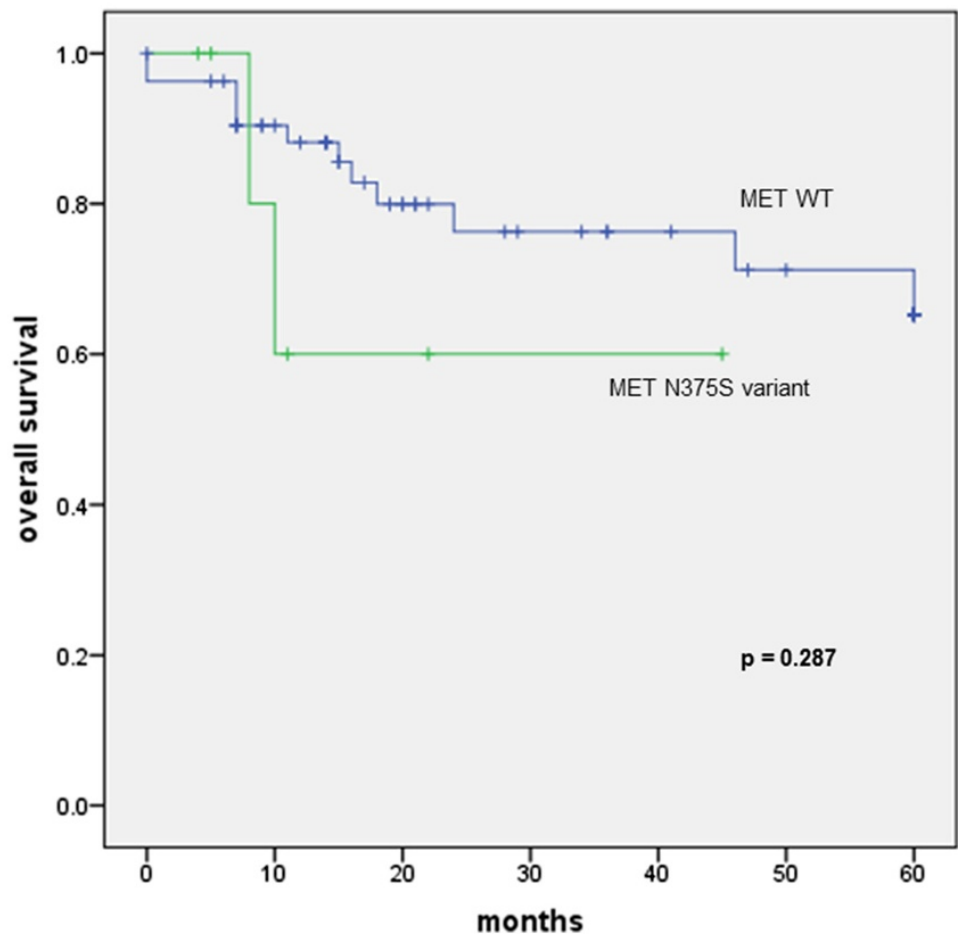

Figure 2 Kaplan-Meier plots showing (a) Locoregional recurrence-free and (b) overall survival in patients with and without the MET N375S variant in the entire cohort. P-value is computed based on the log rank test. Locoregional recurrence rates are significantly higher in patients with the MET $375 S$ variant compared to those without.

profiled for these alterations. In contrast, other Asian cohorts, such as a large series from Korea, identified up to $14 \%$ of EGFR mutations in oral tongue SCC $(n=70)$, suggesting that population differences likely exist [36]. In addition, we did not observe any relationship between age, tobacco use and the prevalence of the mutations tested.

p53 mutations were the most common abnormality identified in $10.6 \%(7 / 66)$ of our patient cohort. While 
this low incidence can be explained by the fact that LungCarta only screens for twelve commonest hotspot mutations in the DNA binding domain, it may also reflect the high proportion of never smokers in our cohort. A recent study in Asian head and neck squamous cell carcinoma found that p53 mutations occurred in approximately $30 \%$ of HNSCC, in contrast to $60-80 \%$ in patients with risk factors such as smoking [43]. We did not find any significant relationship between p53 mutations and outcome, although this is limited by the small sample size.

The other common alteration identified in this panel is a specific MET variant (MET N357S), identified in $10.6 \%(7 / 66)$ of this cohort $[44,45]$. The therapeutic role for inhibiting the MET pathway has yet to be validated, and several trials evaluating targeting MET are ongoing [46-48]. While this is likely a germline variant more commonly present in Asians (13\%), it appears to confer resistance to MET inhibition by inhibiting ligand binding, suggesting that these patients would not benefit from currently available MET inhibitors [49]. Consistent with its role in cancer development, we found that patients with the variant had a poorer outcome than their wild type counterparts, with median loco-regional recurrence-free survival of 11 months compared to 90 months in patients without wild type MET $(\mathrm{p}=0.008)$. Notwithstanding, these results warrant further investigation and should be validated in a larger series, to determine the prognostic value of MET alterations in HNSCC.

Other significant actionable alterations include activating mutations in PIK3CA (seen in 3 patients in our cohort) and STK11 (seen in six patients). These mutations have been described in HNSCC at similar frequencies $[26,38,50]$ and are important considerations when planning future targeted therapy trials in TSCC. Two further mutations identified in this study are novel for TSCC. First, the BRAF mutation (D594G) seen here in one patient has not been previously reported in TSCC, and indeed other BRAF mutations are also exceedingly rare in HNSCC $(<2 \%)$ [51]. The role of BRAF inhibitors targeting non-BRAF V600E cancers remains to be elucidated, although promising activity has been reported [52,53]. NRF2 mutation was also identified in this cohort consistent with the The Cancer Genome Atlas (TCGA) database where mutations in NFEL2 (which is the gene for NRF2) occur in $6 \%$ of HNSCC [24]. NRF2 is a transcription factor that regulates cellular response to oxidative stress by inducing the expression of cytoprotective proteins. It is often overexpressed in human cancers and somatic mutations have been detected in lung cancer [54-56].

The paucity of mutations found using the LungCarta panel suggests that profiling of head and neck cancers would require a more customised approach and a better design of a panel focused on head and neck cancers, and this is in our future pipeline. It is however imperative to ensure high-tumor percentage in tissues examine to ensure that a lack of mutations reflects a true negative result rather than false negatives due to a high proportion of normal cells. If necessary this can be mitigated by macro- or micro-dissection to enrich for tumor cells. Large scale next-generation sequencing efforts from organizations such as TCGA and ICGC would be invaluable in delineating the molecular basis of OSCC. The challenge for the post-genomic/post-discovery era requires implementing pragmatic strategies to identify alterations and pathways that are therapeutically tractable. In this regard, mass spectrometry based mutation profiling is a robust technique that can be applied on frozen or formalin-fixed embedded tissue, and is particularly well-suited for multiplexed screening of hotspot alterations in large patient cohorts [40].

Other issues in this study include a lack of normal patient DNA to confirm that these finding are truly somatic. However, with increasing data available form large scale sequencing efforts and data available in the Cosmic database, panels can be specifically designed to only examine alterations know to be somatic. Notwithstanding it is also important to consider germline variants that can have effects on outcome and therapeutic decisions. The other deficiency with this approach is that it is focused on hotspot mutations which are predictable and limited, and hence not effective in detecting inactivating mutations which tend to be more widely distributed. In this regard, a capture technique (such as those offered by Ion Torrent or Sureselect systems) may be more inclusive. However, unlike Sequenom, the latter often require validation using Sanger sequencing to confirm findings. This study relied on the availability of sufficient tumor specimen to perform these analyses; hence there were fewer small, early T-stage tumors in our cohort than normally seen in the clinic, despite being a consecutive series.

In conclusion, we confirm that common activating EGFR mutations and KRAS mutations are not present in a large cohort of Asian tongue cancers. Molecular profiling using Sequenom MA4 is a robust, reproducible technique in determining clinically relevant mutations e.g. PIK3CA [39,40]. Patient derived cell lines that recapitulate specific genetic changes in the original tumour are important discovery tools that will facilitate further understanding of cell context-specific factors of genetic alterations. Future design of a specific HNSCC panel should take into consideration important actionable mutations identified through the ongoing large scale sequencing efforts.

\section{Abbreviations}

TSCC: Tongue squamous cell carcinomaOSCC, Oral squamous cell carcinoma; TKI: Tyrosine kinase inhibitor; OS: Overall survival; LRFS: Loco-regional recurrence free survival; ICGC: International Cancer Genome Consortium; NSCLC: Non-small cell lung cancer; HNSCC: Head and neck squamous cell carcinoma; HPV: Human papillomavirus; TCGA: The Cancer Genome Atlas. 


\section{Competing interests}

The authors declare that they have no competing interests.

\section{Authors' contributions}

HSL, SPH, DPXL and SSK collected and curated the samples, extracted DNA, and ran the Sequenom experiments. TKHL: assessed the tissue for tumor content prior to extraction. WW and SSK performed the analysis including the subsequent statistics. DSWT and NGI conceived of the study, participated in its design and coordination, and drafted/finalized the manuscript. All authors read and approved the final manuscript.

\section{Acknowledgements}

This work was supported by a Singhealth Foundation grant, and NGI is partly funded through a National Medical Research Council (Singapore) Clinician-Scientist Award.

\section{Author details}

${ }^{1}$ Cancer Therapeutics Research Laboratory, National Cancer Centre Singapore, 11 Hospital Drive, Singapore 169610, Singapore. ${ }^{2}$ Department of Medical Oncology, National Cancer Centre, 11 Hospital Drive, Singapore 169610, Singapore. ${ }^{3}$ Department of Surgical Oncology, National Cancer Centre, 11 Hospital Drive, Singapore 169610, Singapore. ${ }^{4}$ Department of Pathology, Singapore General Hospital, Outram Road, Singapore 169610, Singapore.

Received: 23 June 2014 Accepted: 11 September 2014 Published: 19 September 2014

\section{References}

1. International Agency for Research on Cancer: Globocan 2012. In [http://globocan.iarc.fr]

2. National Cancer Institute: SEER Stat Fact Sheets: Oral Cavity and Pharynx Cancer. In [http://www.seer.cancer.gov/statfacts/html/oralcav.html]

3. Krishna Rao SV, Mejia G, Roberts-Thomson K, Logan R: Epidemiology of oral cancer in Asia in the past decade-an update (2000-2012). Asian Pac J Cancer Prev 2013, 14(10):5567-5577.

4. Yip CS, Charn TC, Wee JT, Tan TW, Goh C, Tan HK, Fong KW: Outcomes of oral tongue cancer: does age matter? Ann Acad Med Singapore 2010, 39:897.

5. Chaturvedi AK, Engels EA, Anderson WF, Gillison ML: Incidence trends for human papillomavirus-related and -unrelated oral squamous cell carcinomas in the United States. J Clin Oncol 2008, 26:612-619.

6. Krishnamurthy A, Ramshankar V: Early stage oral tongue cancer among non-tobacco users - An increasing trend observed in a South Indian patient population presenting at a single centre. Asian Pac J Cancer Prev 2013, 14:5061-5065.

7. Oral cancer incidence statistics. In [http://www.cancerresearchuk.org/cancerinfo/cancerstats/types/oral/incidence/uk-oral-cancer-incidence-statistics]

8. Bodner L, Manor E, Friger MD, van der Waal I: Oral squamous cell carcinoma in patients twenty years of age or younger - Review and analysis of 186 reported cases. Oral Oncol 2014, 50(2):84-89.

9. Patel SC, Carpenter WR, Tyree S, Couch ME, Weissler M, Hackman T, Hayes DN, Shores C, Chera BS: Increasing incidence of oral tongue squamous cell carcinoma in young white women, age 18 to 44 years. J Clin Oncol 2011, 29:1488-1494.

10. Byers RM, Weber RS, Andrews T, McGill D, Kare R, Wolf P: Frequency and therapeutic implications of "skip metastases" in the neck from squamous carcinoma of the oral tongue. Head Neck 1997, 19(1):14-19.

11. Zelefsky MJ, Harrison LB, Fass DE, Armstrong J, Spiro RH, Shah JP, Strong EW: Postoperative radiotherapy for oral cavity cancers: impact of anatomic subsite on treatment outcome. Head Neck 1990, 12(6):470-475.

12. India Project Team of the International Cancer Genome Consortium: Mutational landscape of gingivo-buccal oral squamous cell carcinoma reveals new recurrently-mutated genes and molecular subgroups. Nat Commun 2013, 4:2873.

13. Morris LG, Chan TA: Resistance to EGFR inhibitors: molecular determinants and the enigma of head and neck cancer. Oncotarget 2011, 2(12):894-895

14. Lee CK, Brown C, Gralla RJ, Hirsh V, Thongprasert S, Tsai CM, Tan EH, Ho JC, da Chu T, Zaatar A, Osorio Sanchez JA, Vu W, Au JS, Inoue A, Lee SM, Gebski V, Yang JC: Impact of EGFR inhibitor in non-small cell lung cancer on progression-free and overall survival: a meta-analysis. J Natl Cancer Inst 2013, 105(9):595-605.

15. Cohen EE, Halpern AB, Kasza K, Kocherginsky M, Williams R, Vokes EE: Factors associated with clinical benefit from epidermal growth factor receptor inhibitors in recurrent and metastatic squamous cell carcinoma of the head and neck. Oral Oncol 2009, 45:e155-e160.

16. Bontognali S, Pless M, Brutsche MH, Fischer C, Rochlitz C, Buess M: Analysis of the EGFR mutation status in head and neck squamous cell carcinoma before treatment with Gefitinib. Onkologie 2013, 36(4):161-166.

17. Stewart JS, Cohen EE, Licitra L, Van Herpen CM, Khorprasert C, Soulieres D, Vodvarka P, Rischin D, Garin AM, Hirsch FR, Varella-Garcia M, Ghiorghiu S, Hargreaves L, Armour A, Speake G, Swaisland A, Vokes EE: Phase III study of gefitinib compared with intravenous methotrexate for recurrent squamous cell carcinoma of the head and neck [corrected]. J Clin Oncol 2009, 27(11):1864-1871.

18. Kirby AM, A'Hern RP, D'Ambrosio C, Tanay M, Syrigos KN, Rogers SJ, Box C, Eccles SA, Nutting CM, Harrington KJ: Gefitinib (ZD1839, Iressa) as palliative treatment in recurrent or metastatic head and neck cancer. $\mathrm{Br} J$ Cancer 2006, 94(5):631-636.

19. Cohen EE, Kane MA, List MA, Brockstein BE, Mehrotra B, Huo D, Mauer AM, Pierce C, Dekker A, Vokes EE: Phase II trial of gefitinib $250 \mathrm{mg}$ daily in patients with recurrent and/or metastatic squamous cell carcinoma of the head and neck. Clin Cancer Res 2005, 11:8418-8424.

20. Wheeler RH, Jones D, Sharma P, Davis RK, Spilker H, Boucher K, Leachman S, Grossman D, Salzman K, Akerley W: Clinical and molecular Phase II study of gefitinib in patients (pts) with recurrent squamous cell cancer of the head and neck (H\&N Ca). J Clin Oncol 2005, 23:5531. Meeting Abstracts.

21. Cohen EE, Rosen F, Stadler WM, Recant W, Stenson K, Huo D, Vokes EE: Phase II trial of ZD1839 in recurrent or metastatic squamous cell carcinoma of the head and neck. J Clin Oncol 2003, 21(10):1980-1987.

22. Thomas F, Rochaix P, Benlyazid A, Sarini J, Rives M, Lefebvre JL, Allal BC, Courbon F, Chatelut E, Delord JP: Pilot study of neoadjuvant treatment with erlotinib in nonmetastatic head and neck squamous cell carcinoma. Clin Cancer Res 2007, 13(23):7086-7092.

23. Soulieres D, Senzer NN, Vokes EE, Hidalgo M, Agarwala SS, Siu LL: Multicenter phase II study of erlotinib, an oral epidermal growth factor receptor tyrosine kinase inhibitor, in patients with recurrent or metastatic squamous cell cancer of the head and neck. J Clin Oncol 2004, 22(1):77-85

24. The Cancer Genome Atlas. In [https://tcga-data.nci.nih.gov/tcga/]

25. Catalogue of somatic mutations in cancer (COSMIC). In [http://cancer. sanger.ac.uk/cancergenome/projects/cosmic/]

26. Agrawal N, Frederick MJ, Pickering CR, Bettegowda C, Chang K, Li RJ, Fakhry C, Xie TX, Zhang J, Wang J, Zhang N, El-Naggar AK, Jasser SA, Weinstein JN, Treviño L, Drummond JA, Muzny DM, Wu Y, Wood LD, Hruban RH, Westra WH, Koch WM, Califano JA, Gibbs RA, Sidransky D, Vogelstein B, Velculescu VE, Papadopoulos N, Wheeler DA, Kinzler KW, et al: Exome sequencing of head and neck squamous cell carcinoma reveals inactivating mutations in NOTCH1. Science 2011, 333:1154-1157.

27. Stransky N, Egloff AM, Tward AD, Kostic AD, Cibulskis K, Sivachenko A, Kryukov GV, Lawrence MS, Sougnez C, McKenna A, Shefler E, Ramos AH, Stojanov P, Carter SL, Voet D, Cortés ML, Auclair D, Berger MF, Saksena G, Guiducci C, Onofrio RC, Parkin M, Romkes M, Weissfeld JL, Seethala RR, Wang L, Rangel-Escareño C, Fernandez-Lopez JC, Hidalgo-Miranda A, Melendez-Zajgla J, et al: The mutational landscape of head and neck squamous cell carcinoma. Science 2011, 333:1157-1160.

28. Hsieh CH, Chang JW, Hsieh JJ, Hsu T, Huang SF, Liao CT, Wang HM: Epidermal growth factor receptor mutations in patients with oral cavity cancer in a betel nut chewing-prevalent area. Head Neck 2011, 33(12):1758-1764.

29. Huang SF, Chuang WY, Chen $H$, Liao CT, Wang HM, Hsieh LL: EGFR protein overexpression and mutation in areca quid-associated oral cavity squamous cell carcinoma in Taiwan. Head Neck 2009, 31(8):1068-1077.

30. Sheikh Ali MA, Gunduz M, Nagatsuka H, Gunduz E, Cengiz B, Fukushima K, Beder LB, Demircan K, Fujii M, Yamanaka N, Shimizu K, Grenman R, Nagai N: Expression and mutation analysis of epidermal growth factor receptor in head and neck squamous cell carcinoma. Cancer Sci 2008, 99:1589-1594.

31. Lemos-González Y, Páez de la Cadena M, Rodríguez-Berrocal FJ, Rodríguez-Piñeiro AM, Pallas E, Valverde D: Absence of activating mutations in the EGFR kinase domain in Spanish head and neck cancer patients. Tumour Biol 2007, 28(5):273-279. 
32. Na II, Kang HJ, Cho SY, Koh JS, Lee JK, Lee BC, Lee GH, Lee YS, Yoo HJ, Ryoo BY, Yang SH, Shim YS: EGFR mutations and human papillomavirus in squamous cell carcinoma of tongue and tonsil. Eur J Cancer 2007, 43:520-526.

33. Chung $\mathrm{CH}$, Ely K, McGavran L, Varella-Garcia M, Parker J, Parker N, Jarrett C, Carter J, Murphy BA, Netterville J, Burkey BB, Sinard R, Cmelak A, Levy S, Yarbrough WG, Slebos RJ, Hirsch FR: Increased epidermal growth factor receptor gene copy number is associated with poor prognosis in head and neck squamous cell carcinomas. J Clin Oncol 2006, 24(25):4170-4176.

34. Loeffler-Ragg J, Witsch-Baumgartner M, Tzankov A, Hilbe W, Schwentner I, Sprinzl GM, Utermann G, Zwierzina H: Low incidence of mutations in EGFR kinase domain in Caucasian patients with head and neck squamous cell carcinoma. Eur J Cancer 2006, 42(1):109-111.

35. Lee JW, Soung YH, Kim SY, Nam HK, Park WS, Nam SW, Kim MS, Sun DI, Lee YS, Jang JJ, Lee JY, Yoo NJ, Lee SH: Somatic mutations of EGFR gene in squamous cell carcinoma of the head and neck. Clin Cancer Res 2005, 11(8):2879-2882.

36. Cohen EE, Lingen MW, Martin LE, Harris PL, Brannigan BW, Haserlat SM, Okimoto RA, Sgroi DC, Dahiya S, Muir B, Clark JR, Rocco JW, Vokes EE, Haber DA, Bell DW: Response of some head and neck cancers to epidermal growth factor receptor tyrosine kinase inhibitors may be linked to mutation of ERBB2 rather than EGFR. Clin Cancer Res 2005, 11:8105-8108.

37. Willmore-Payne C, Holden JA, Layfield LJ: Detection of EGFR- and HER2-activating mutations in squamous cell carcinoma involving the head and neck. Mod Pathol 2006, 19(5):634-640.

38. Nguyen TK, lyer NG: Genetic alterations in head and neck squamous cell carcinoma: The next-gen sequencing era. World J Med Genet 2013, 3:22-33.

39. Zanaruddin SN, Yee PS, Hor SY, Kong YH, Ghani WM, Mustafa WM, Zain RB, Prime SS, Rahman ZA, Cheong SC: Common oncogenic mutations are infrequent in oral squamous cell carcinoma of Asian origin. PLoS One 2013, 8(11):e80229.

40. Tan DS, Camilleri-Broët S, Tan EH, Alifano M, Lim WT, Bobbio A, Zhang S, Ng QS, Ang MK, lyer NG, Takano A, Lim KH, Régnard JF, Tan P, Broët P: Intertumour heterogeneity of non-small cell lung carcinomas revealed by multiplexed mutation profiling and integrative genomics. Int J Cancer 2014, 135(5):1092-1100.

41. Fumagalli D, Gavin PG, Taniyama Y, Kim SI, Choi HJ, Paik S, Pogue-Geile KL: A rapid, sensitive, reproducible and cost-effective method for mutation profiling of colon cancer and metastatic lymph nodes. BMC Cancer 2010 10:101. doi:10.1186/1471-2407-10-101.

42. Leong HS, Chong FT, Sew PH, Lau DP, Wong BH, Teh BT, Tan DS, lyer NG: Targeting Cancer Stem Cell Plasticity Through Modulation of Epidermal Growth Factor and Insulin-Like Growth Factor Receptor Signaling in Head and Neck Squamous Cell Cancer. Stem Cells Trans/ Med 2014 3(9):1055-1065. doi:10.5966/sctm.2013-2014. Epub 2014 Jul 14.

43. Riethdorf S, Friedrich RE, Ostwald C, Barten M, Gogacz P, Gundlach KK, Schlechte H, Becker J, Bregenzer T, Riethdorf L, Löning T: p53 gene mutations and HPV infection in primary head and neck squamous cell carcinomas do not correlate with overall survival: a long-term follow-up study. J Oral Pathol Med 1997, 26(7):315-321.

44. Hunt JL, Barnes L, Lewis JS Jr, Mahfouz ME, Slootweg PJ, Thompson LD, Cardesa A, Devaney KO, Gnepp DR, Westra WH, Rodrigo JP, Woolgar JA Rinaldo A, Triantafyllou A, Takes RP, Ferlito A: Molecular diagnostic alterations in squamous cell carcinoma of the head and neck and potential diagnostic applications. Eur Arch Otorhinolaryngol 2014, 271(2):211-223.

45. Linehan WM, Ricketts CJ: The metabolic basis of kidney cancer. Semin Cancer Biol 2013, 23:46-55.

46. Seiwert TY, Jagadeeswaran R, Faoro L, Janamanchi V, Nallasura V, El Dinali M, Yala S, Kanteti R, Cohen EE, Lingen MW, Martin L, Krishnaswamy S, KleinSzanto A, Christensen JG, Vokes EE, Salgia R: The MET receptor tyrosine kinase is a potential novel therapeutic target for head and neck squamous cell carcinoma. Cancer Res 2009, 69:3021-3031.

47. Peters $S$, Adjei AA: MET: A promising anticancer therapeutic target. Nat Rev Clin Oncol 2012, 9:314-326.

48. Knudsen BS, Vande Woude G: Showering c-MET-dependent cancers with drugs. Curr Opin Genet Dev 2008, 18:87-96.

49. Shieh JM, Tang YA, Yang TH, Chen CY, Hsu HS, Tan YH, Salgia R, Wang YC: Lack of association of C-Met-N375S sequence variant with lung cancer susceptibility and prognosis. Int J Med Sci 2013, 10:988-994.
50. Qiu W, Schönleben F, Thaker HM, Goggins M, Su GH: A novel mutation of STK11/LKB1 gene leads to the loss of cell growth inhibition in head and neck squamous cell carcinoma. Oncogene 2006, 25:2937-2942.

51. Weber A, Langhanki L, Sommerer F, Markwarth A, Wittekind C, Tannapfel A: Mutations of the BRAF gene in squamous cell carcinoma of the head and neck. Oncogene 2003, 22:4757-4759.

52. Falchook GS, Long GV, Kurzrock R, Kim KB, Arkenau TH, Brown MP, Hamid O, Infante JR, Millward M, Pavlick AC, O'Day SJ, Blackman SC, Curtis CM, Lebowitz P, Ma B, Ouellet D, Kefford RF: Dabrafenib in patients with melanoma, untreated brain metastases, and other solid tumours: a phase 1 dose-escalation trial. Lancet 2012, 19;379(9829):1893-2901.

53. Bahadoran P, Allegra M, Le Duff F, Long-Mira E, Hofman P, Giacchero D, Passeron T, Lacour JP, Ballotti R: Major clinical response to a BRAF inhibitor in a patient with a BRAF L597R-mutated melanoma. J Clin Oncol 2013, 31:e324-e326.

54. Stacy DR, Ely K, Massion PP, Yarbrough WG, Hallahan DE, Sekhar KR, Freeman ML: Increased expression of nuclear factor E2 p45-related factor 2 (NRF2) in head and neck squamous cell carcinomas. Head Neck 2006, 28:813-818.

55. Shibata T, Saito S, Kokubu A, Suzuki T, Yamamoto M, Hirohashi S: Global downstream pathway analysis reveals a dependence of oncogenic NF-E2 Related factor 2 mutation on the mTOR growth signaling pathway. Cancer Res 2010, 70:9095-9105.

56. Kim YR, Oh JE, Kim MS, Kang MR, Park SW, Han JY, Eom HS, Yoo NJ, Lee SH: Oncogenic NRF2 mutations in squamous cell carcinomas of oesophagus and skin. J Pathol 2010, 220:446-451.

doi:10.1186/1471-2407-14-679

Cite this article as: Tan et al:: Tongue carcinoma infrequently harbor common actionable genetic alterations. BMC Cancer 2014 14:679.

\section{Submit your next manuscript to BioMed Central and take full advantage of:}

- Convenient online submission

- Thorough peer review

- No space constraints or color figure charges

- Immediate publication on acceptance

- Inclusion in PubMed, CAS, Scopus and Google Scholar

- Research which is freely available for redistribution

Submit your manuscript at www.biomedcentral.com/submit
C) Biomed Central 